Georgetown University Law Center

Scholarship @ GEORGETOWN LAW

2010

\title{
Neuroscience and the Free Exercise of Religion
}

Steven Goldberg

Georgetown University Law Center, goldberg@law.georgetown.edu

This paper can be downloaded free of charge from:

https://scholarship.law.georgetown.edu/facpub/86

Steven Goldberg, Neuroscience and the Free Exercise of Religion, in LAW AND NEUROSCIENCE: CURRENT LEGAL ISSUES (M. Freeman, ed., Oxford: Oxford University Press 2010).

This open-access article is brought to you by the Georgetown Law Library. Posted with permission of the author. Follow this and additional works at: https://scholarship.law.georgetown.edu/facpub

Part of the Religion Law Commons, and the Science and Technology Law Commons 


\title{
GEORGETOWN LAW Faculty Publications
}

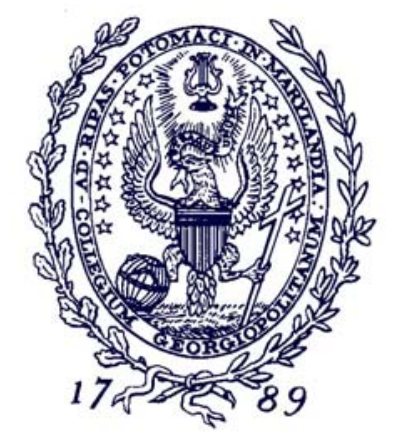

Georgetown Public Law and Legal Theory Research Paper No. 10-01 January 2010

\section{Neuroscience and the Free Exercise of Religion}

\author{
in \\ LAW AND NeURosCIENCE: CURRENT LEGAL ISSUES \\ (M. Freeman, ed., Oxford: Oxford University Press 2010)
}

\section{Steven Goldberg}

Professor of Law

Georgetown University Law Center

goldberg@law.georgetown.edu

This paper can be downloaded without charge from:

Scholarly Commons: http://scholarship.law.georgetown.edu/facpub/86

SSRN: http://ssrn.com/abstract $=1537355$

Posted with permission of the author 


\section{Neuroscience and the Free Exercise of Religion}

\section{Steven Goldberg*}

\section{Introduction}

Dr. Michael Persinger, a prominent neuroscientist and author, can stimulate your right temporal lobe and quite possibly cause you to experience a sense that something God-like is in the room. ${ }^{1}$ Persinger draws no small conclusions from this. "What is the last illusion that we must overcome as a species?," he asks. And he answers: "That illusion is that God is an absolute that exists independent of the human brain - that somehow we are in his or her care." 2

Professor Michael Gazzaniga, head of a leading academic Center for the Study of the Mind, relies on studies showing that specific parts of the brain are activated when people make moral judgments to conclude that religious teachings must give way to what he calls a "universal ethics."3 "It is not a good idea to kill," according to Gazzaniga, "because it is not a good idea to kill, not because God or Allah or Buddha said it was not a good idea to kill.",

Other scholars and commentators have supported variations on these themes, concluding, for example, that modern neuroscience undermines belief in a monotheistic God or in the Bible. ${ }^{5}$ Still others maintain that brain imaging studies fit perfectly with support for "militant atheism.",

\footnotetext{
* James and Catherine Denny Professor of Law, Georgetown University Law Center, Washington, DC. I would like to thank Miriam Goldberg, Louis Michael Seidman, and Girardeau Spann for their comments and suggestions.

${ }^{1}$ Professor Michael A. Persinger, the author of Neuropsychological Bases of God Beliefs (Santa Barbara, California, 1987), discussed this aspect of his work on National Public Radio on 19 May, 2009. See

$<$ http://www.npr.org/templates/story/story.php?storyId=104291534> (accessed 16 July 2009).

2 ibid.

${ }^{3}$ Michael S. Gazzaniga, The Ethical Brain (New York, 2005) 163-178.

${ }^{4}$ ibid 165.

${ }^{5}$ Bennett Gordon, 'Neuroscience Could Be Killing God' (June 4, 2008) Utne Reader $<$ http://www.utne.com/2008-06-04/SpiritualityNeuroscience-Could-Be-Killing-God.aspx> (accessed 16 July 2009).

${ }^{6}$ Kelly Bulkeley, 'The Cognitive Revolution and the Decline of Monotheism' (May 30, 2008), The Immanent Frame < http://www.ssrc.org/blogs/immanent_frame/2008/05/30/the-cognitive-revolution-and the-decline-0f-monotheism/> (accessed 16 July 2009).
} 
If these beliefs take hold in popular culture, they could, over time, have substantial implications for the legal status of religion. If you look across the United States and Europe you will see variation in how free exercise of religion claims are handled, yet you will nonetheless see a broad consensus that religious practices should be respected and tolerated unless they disrupt public order. ${ }^{7}$ But that consensus might erode if religion came to be seen as simply a byproduct of biology and not a very attractive byproduct at that. And, needless to say, the establishments of religion that linger in some European countries ${ }^{8}$ would also have difficulty surviving a transformed view of religion as a branch of neurology.

Neuroscience will not, however, fundamentally undermine the social and legal status of religion. We know this is so for two reasons. First, those who believe brain science erases supernatural religion have logical and philosophical hurdles they have not begun to surmount. Secondly, and more importantly, the challenges that are being raised today have been with us for over one hundred years and have had little to no impact.

\section{Neuroscience, Metaphysics, and Ethics}

As to the first point, there simply is a lot more intellectual work to be done to make the case that neuroscience decisively undermines religious belief. Persinger's apparent belief that empirical testing can falsify supernatural claims is baffling. Karl Popper himself made clear that science simply cannot speak to the truth of metaphysics. That is the whole point of saying that scientific claims must be falsifiable. Progress in science has come from the recognition that the statement "God exists" is not scientific because it is not testable. Thus alleged scientific proofs of God's existence are, in fact, undermined by the modern approach to science. But that is completely different from saying that "God exists" is false. Science cannot tell us that. ${ }^{9}$

\footnotetext{
${ }^{7}$ See eg J. Tomasso, 'Separation of the Conjoined Twins: A Comparative Analysis of the Rights to Privacy and Religious Freedom in Great Britain and the United States' (2002) 54 Rutgers Law Review 771.

${ }^{8}$ See eg C. Evans and C. Thomas, 'Church-State Relations in the European Court of Human Rights' (2006) 2006 Brigham Young University Law Review 699.

${ }^{9}$ For an account of Popper's thinking on metaphysics, see eg Stephen Mumford, 'Metaphysics' in (eds.) Stathis Psillos and Martin Curd, The Routledge Companion to Philosophy of Science (London, 2008), 2635. Mumford makes clear that Popper's views are disputed by many philosophers, but it remains true that Popper has the "largest methodological influence on actual scientists" in modern times. S. O'Connor, 'The Supreme Court’s Philosophy of Science: Will the Real Karl Popper Please Stand Up?' (1995) 35 Jurimetrics Journal 276. For further support for the proposition that "neuroscience ultimately cannot disprove a metaphysical soul,” see Paul Root Wolpe, 'Religious Responses to Neuroscientific Questions' in
} 
As Popper himself put it, falsifiability is:

A criterion of demarcation between empirical science on the one hand and pure mathematics, logic, metaphysics, and pseudo-science on the other.... The broad line of demarcation between empirical science ... and ... metaphysics ... has to be drawn right through the very heart of the region of sense - with meaningful theories on both sides of the dividing line - rather than between the region of sense and nonsense. ${ }^{10}$

But does Persinger level at least a practical attack on religion? Here, too, his position is wanting. Suppose stimulation of the brain by a clinician triggers a religious experience. That might undermine the faith of someone who thought only God could trigger such an experience. But many people of faith would have no difficulty in accepting that God can also do what a clinician can do. After all, neuroscientific studies have shown that placebos operate on the pathways of pain in much the same way as opiates. ${ }^{11}$ If a placebo can trigger the brain, it would be odd to suppose God could not. And of course for many it is God who made sure in the first place that people have brains that can experience the spiritual.

It is also hard to give great weight to Gazzaniga's notion that our knowledge of the brain will lead to a universal ethics which will supplant traditional religions. First there is his apparent commission of the naturalistic fallacy. He seems to assume that what is tells us what ought to be. But any serious study of the brain, just like any serious study of the Bible, would turn up substantial evidence that some people are predisposed to enslave others. ${ }^{12}$ Yet that does not make slavery morally acceptable.

Even when brain science allegedly uncovers a helpful moral teaching, Gazzaniga's hope for a universal ethics is not very promising. He finds that, in certain settings, people believe that we should not kill. But a cursory

(ed.) Judy Illes, Neuroethics: Defining the Issues in Theory, Practice, and Policy (Oxford, 2006), 289, 292293.

${ }^{10}$ Karl Popper, Realism and the Aim of Science ( London, 1992) 175-176 (emphasis in the original).

11 A. J. Kolber, ‘A Limited Defense of Clinical Placebo Deception' (2007) 26 Yale Law \& Policy Review 89-90.

${ }^{12}$ The acceptance of slavery in the Old and New Testament and in other religious texts along with the persistence of slavery in modern times are among the topics discussed in B.K. Freemon, 'Slavery, Freedom, and the Doctrine of Consensus in Islamic Jurisprudence' (1998) 11 Harvard Human Rights Journal 1. 
glance around the globe suggests that we do, as a species, differ quite a bit on issues like pacifism and capital punishment. In a world in which abortion ranges from a crime to a constitutional right, we may have to put the emergence of a universal ethics based on science on hold for a little while.

\section{William James and the Lessons of History}

Yet the biggest problem with the neuroscientific attack on religion is that we have been through this before, and religion has emerged essentially unscathed. By the early days of the twentieth century, medicine and science had progressed to the point where the ecstatic experiences of great religious leaders were often attributed to physical abnormalities: Saint Paul was viewed as an epileptic, Saint Teresa as an hysteric, and so on. ${ }^{13}$

It was against this backdrop that William James delivered the Gifford Lectures on Natural Religion at the University of Edinburgh. James' talks, published in 1902 as The Varieties of Religious Experience, took as their subject precisely the subjective experiences of those religious visionaries who often fell into trances, heard voices, saw visions, and the like. ${ }^{14}$ James had no interest in the "ordinary religious believer who follows the conventional observances" of Christianity or any other faith. ${ }^{15}$ He said that it "would profit us little to study this second-hand religious life" marked as it was by "fixed forms of imitation and retained by habit."16 James was interested precisely in people like Saint Paul.

As a philosopher and a psychologist who also had a medical degree, James was well situated to address religion and the mind. And, indeed, he began his talk by arguing that to "plead the organic causation of a religious state of mind ... in refutation of its claim to possess superior spiritual value is quite illogical and arbitrary...." ${ }^{17}$ We cannot improve upon the reason he gave:

${ }^{13}$ William James, The Varieties of Religious Experience: A Study in Human Nature (New York 2008 edition) 16.

14 ibid.

${ }^{15}$ ibid 10.

${ }^{16}$ ibid.

17 ibid 17. James concludes this sentence by saying, "unless one has already worked out in advance some psycho-physical theory connecting spiritual values in general with determinate sorts of physiological change." ibid. James here is rejecting the idea that an experience produced by a certain part of the brain is morally superior because that part of the brain is somehow privileged. He writes that "medical materialism ... has no physiological theory of the production of ... its favorite states, by which it may accredit them; 
[T] or morbid, that has not some organic process as its condition. Scientific theories are organically conditioned just as much as religious emotions are; and if we only knew the facts intimately enough, we should doubtless see "the liver" determining the dicta of the sturdy atheist as decisively as it does those of the Methodist.... ${ }^{18}$

Today it is popular to give functional MRIs to see how the brain is behaving when religious or moral sentiments are under consideration. In the future it may be equally popular to scan the brains of scientists while they think about dark matter or superstring theory or neuroscience itself. The results may be fascinating, but they will tell us nothing about the merits of the topics on the thinkers' minds.

Since William James, the subject of the connection between our physical selves and our religious beliefs has come up time and again. Just fifteen years ago, when the Human Genome Project, rather than brain scanning, was the reductionist theory of the day, the cover of Time Magazine announced the discovery of The God Gene and asked "Does our DNA compel us to seek a higher power?”19

The God Gene turned out to be hard to pin down. But the bigger point is that it scared very few people of faith. Just as with the results of MRIs, a gene for religion that is seen by some as an evolutionary adaptation that undermines God is taken by others as evidence that God himself has hard wired us for faith. ${ }^{20}$

Indeed in recent years, religious organizations, far from being cowed by developments in brain science, have sponsored conferences that have featured presentations on the compatibility of neuroscience and faith. At the Woodstock Theological Center, Dr. Malcolm Jeeves argued that "all the evidence in neuroscience points to us as a ... unity....[T]here are these intimate relations between mental life, emotional life and neural structures,

and its attempt to discredit the states which it dislikes, by vaguely associating them with nerves and liver, and connecting them with names connoting bodily affliction, is altogether illogical and inconsistent." ibid. ${ }^{18}$ ibid.

19 'The God Gene: Does our DNA Compel Us to Seek a Higher Power? Believe It or Not, Some Scientists Say Yes’ Time (October 25, 2004)(Cover).

20 See eg Dean Hamer, The God Gene: How Faith is Hardwired into our Genes (New York , 2004). 
including the spiritual dimension." ${ }^{21}$ By the spiritual dimension, Jeeves said, "I mean essentially a relationship with God however you formulate that.",22 At the Center for Theology and the Natural Sciences' conference on Neuroscience, Religious Experience and the Self, Professor David Ray Griffin concluded that "the existence and persistence of religion," including "a direct experience ... of a Holy Actuality" is consistent with the scientific point of view. ${ }^{23}$

It is reasonable to wonder why people of faith are comfortable with neuroscience while many remain deeply troubled by the theory of evolution. Neuroscience, after all, is completely embedded in and dependent on the evolutionary framework: working neuroscientists are not likely to be creationists.

While it is, of course, possible to reconcile evolution with belief in God, there is no denying that Darwin's work caused a crisis in traditional religion. ${ }^{24}$ Why is neuroscience not doing the same?

The reason is that evolution is not simply a set of facts, or a model, or an increase in our knowledge about the material nature of human beings. Evolution is a narrative. It is a story about who we are and where we are going. From a human point of view, it is not a particularly uplifting narrative, indeed it is not even centered on humans. And evolution is a counter-narrative to that told by traditional religions. They tell a story in which we are specially created and have a special destiny. Giving up a central narrative that gives meaning to our existence is not easy.

Consider the argument put forward by Ron Carlson and Ed Decker in their book, Fast Facts on False Teachings, in which they defend evangelical Christianity and attack evolution. Carlson and Decker write that according to evolution, "You are the descendant of a tiny cell of primordial protoplasm washed up on an ocean beach $31 / 2$ billion years ago....Y You are a mere grabbag of atomic particles, a conglomeration of genetic substance.... [Y]ou came from nothing, you are going nowhere."25 The Christian view, in

\footnotetext{
${ }^{21}$ Malcolm Jeeves, 'Neuroscience and the Soul’ (1998) 1998 Woodstock Forum 19.

${ }^{22}$ ibid.

${ }^{23}$ David Ray Griffin, 'Scientific Naturalism, The Mind-Body Relation, and Religious Experience' (2002)

37 Zygon 376.

${ }^{24}$ See eg Steven Goldberg, Seduced By Science: How American Religion Has Lost Its Way (New York, 1999) 25-39.

${ }^{25}$ Ron Carlson and Ed Decker, Fast Facts on False Teachings (Eugene, Oregon, 1994) 62.
} 
contrast, says, "You are the special creation of a good and all-powerful God. You are the climax of His creation.... [Y]]ou are unique.... Your Creator love[s] you."26

Unlike evolution, neuroscience can be seen as simply providing a deeper understanding of the wonderfully complex special brain that God has given us. And those neuroscientists who think that the discipline's deterministic framework is somehow inconsistent with religion need to meet some Calvinists.

\section{Incremental Legal Change As Law Reacts to Neuroscience}

So neuroscience will not fatally undermine religion or fundamentally erode its legal status. But that is only half of the story.

Recent research in brain science will play a role in the law in a manner that is typical of scientific advances. The role will be modest rather than grandiose, incremental rather than sweeping. Advocates for a party in a dispute will seek to use current research findings as part of their effort to advance their cause. If the courts judge the proffered evidence to be sufficiently reliable the evidence will be admitted. It may then play a part in the tribunal's final decision. An individual litigated matter will not necessarily have broad implications, but over time the underlying science may become a feature of certain disputes.

Under this scenario, neuroscience could play a role in law and religion disputes in the courtroom, just as it can play a role in other legal settings. Let me give a hypothetical example to clarify my point before turning to a few actual cases that have already arisen.

Under current law in many American states, parents can be excused from their ordinary obligation to give their children traditional medical treatment when the parents object on religious grounds. ${ }^{27}$ Christian Scientists are the main beneficiaries of this religious exemption. This

${ }^{26}$ ibid 63.

${ }^{27}$ For a discussion, with references, of the material in this paragraph, see Kei Robert Hirasawa, 'Are Parents Acting in the Best Interests of their Children When They Make Medical Decisions Based on Their Religious Beliefs?’ (2006) 44 Family Court Review 318. 
statutory exemption, where it exists, is not unlimited. Parents, regardless of their religious beliefs, are never free to prevent their children from receiving life saving care. But when a treatment is related to health rather than life, and a parent chooses to use prayer rather than conventional medicine, that parent will be immune from child neglect charges in certain states.

As with all legal doctrines, hard cases can arise under these statutes. How dangerous is the child's illness? Are the parents' objections really based on religion, as required by the statute? These kinds of issues are determined on a case-by-case basis.

So consider the following hypothetical case. A single father has a young daughter with a serious arm injury. The doctor wants to intervene with antibiotics. The father, who is not affiliated with any organized religious group and has not been to church for years, suddenly announces that he will pray over his daughter rather than bring her back to the doctor's office. He says that he is hearing voices from God telling him to keep his daughter at home.

When the matter comes before a judge, she is quite troubled. She is concerned that the child could have an infection that will become very serious. She knows that under the statutory exception for religious practice it should not matter whether the father is a member of an organized church, but she is concerned that his statements are better described as erratic or troubled rather than religious.

Suppose now that the state, in an effort to force treatment, introduces neuroscientific evidence that the father's experience of hearing voices is typical of a particular brain abnormality usually viewed as a type of mental illness. Perhaps the state has even obtained brain scans of the father that support this view.

I believe it is quite plausible that this neuroscientific evidence could play a role in the judge deciding that treatment should be given to the daughter over the father's objection. Technically, the judge might find that the father's objections are not religious under the statute, although the decision could also involve a stated or unstated concern that the injury could be potentially life threatening. My point is simply that the neuroscience might matter to this judge. 
The immediate objection to this prediction is that it appears to flatly contradict our earlier observation that neuroscience will not undermine religion. What happened to the arguments we heard a moment ago? Attributing the voice of God that the father is hearing to a particular part of his brain should not undermine that voice any more than attributing a doctor's brilliant diagnosis to a part of the doctor's brain should undermine the diagnosis.

The answer is that there is a contradiction, but it is one that we see in the law every day. Consider the insanity defense, which negates criminal liability if because of mental illness an individual cannot tell right from wrong. ${ }^{28}$ Why do we regard an individual as not guilty by reason of insanity if his moral compass has been thrown off by a mental defect, but not if it has been impaired by extreme poverty or drug addition? Surely it is the brain that is implicated in all of these cases.

Or consider the doctrine in some jurisdictions that excuses you from a contract if you entered into the deal under the compulsion of a mental disease. ${ }^{29}$ To a philosopher or a scientist any contract you made might be traced back to your genetic endowment, your upbringing, and the latest advertisements you saw, but that sort of compulsion argument will never work.

Obviously the courtroom plays fast and loose with deep philosophical ideas like determinism. The legal system's treatment of these concepts is rarely logically consistent. Instead the law treats new scientific theories on a rather ad hoc basis until some sort of broad societal consensus arises.

There are two primary reasons judicial decision makers do not seek scientific and philosophical consistency above all else. ${ }^{30}$ First, in resolving a case, a judge is seeking a peaceful and socially acceptable resolution of a dispute. People need a chance to be heard, values like religious liberty and child welfare need to be weighed, public understanding needs to be considered. The accurate resolution of a factual dispute is not the only, or even the primary, goal.

\footnotetext{
28 See eg M’Naghten’s Case, 8 Eng. Rep. 718, 722 (H. L. 1843).

29 See eg Faber v. Sweet Style Mfg. Corp., 242 N.Y.S. 2d 763 (Sup. Ct. NY 1963).

30 I have discussed the material in this and the succeeding paragraph in Steven Goldberg, Culture Clash: Law and Science in America (New York, 1994) 13-20.
} 
Secondly, every judge understands that not to decide is a decision. If a judge said, "I won't order a young child to receive treatment until there is complete consensus on the neuroscience underlying the voices the father is hearing, and full philosophical agreement on whether the father had a real choice in making his decision," then no child would ever be treated over the parent's objection. And if the judge put the burden on the parent to prove beyond any doubt his scientific and philosophical assumptions then religious liberty would never be respected. The law doesn't have the luxury of waiting, so it moves along, case by case, making imperfect decisions in the best way it can.

It is not that there are no relevant legal presumptions here. Whether it be religious belief, criminal responsibility, or the making of contracts, the law, as Justice Cardozo put it, begins "with a robust common sense which assumes the freedom of the will as a working hypothesis." 31 But, as Cardozo well knew, there are places where we put this assumption aside.

\section{Recent Cases}

Although it did not involve religion, there has already been one major United States Supreme Court case where modern brain science played a role. In Roper v. Simmons, the Court, in 2005, ruled that it violated the Constitution for the state of Missouri to execute individuals who were under the age of eighteen when their crimes were committed. ${ }^{32}$ In finding that the death penalty in those instances constituted cruel and unusual punishment, the Court relied in part on an amicus brief filed on behalf of scientists and doctors which argued that adolescent brain development is immature because the frontal lobe is not fully developed, and it is this part of the brain that is responsible for impulse control and good judgment. ${ }^{33}$

One can already hear the shouts of protests. When the frontal lobe is fully developed, does that mean that free will magically appears? And does this maturing of the lobe happily take place precisely when one turns eighteen? And so on.

\footnotetext{
31 Steward Machine Co. v. Davis, 301 U.S. 548, 590 (1937).

32 Roper v. Simmons, 543 U.S. 551 (2005).

33 ibid 569-570. See also A. Haider, 'Roper v. Simmons: The Role of the Science Brief' (2006) 3 Ohio State Journal of Criminal Law 369.
} 
But the Court knew all this and more. Its decision drew strength from the emerging field of neuroscience - and science does lend some prestige to a judicial ruling - but it relied as well on precedent, on the unwillingness to execute children in most American states and in most countries around the world, and on a broader discomfort with the death penalty itself. ${ }^{34}$ Even when the Court referenced the scientific studies, it did so in a cautious way, embedding them in common sense and legislative judgments:

[A]s any parent knows and as the scientific and sociological studies respondent and his amici cite tend to confirm, "[a] lack of maturity and an underdeveloped sense of responsibility are found in youth more often than in adults and are more understandable among the young. These qualities often result in impetuous and ill-considered actions and decisions." .... In recognition of the comparative immaturity and irresponsibility of juveniles, almost every State prohibits those under 18 years of age from voting, serving on juries, or marrying without parental consent.... 35

So in the field of law and religion, I would expect neuroscience to make some limited but important appearances in the years ahead. There already are some cases of this type. In 2008, the Minnesota Court of Appeals affirmed a decision by a district court civilly committing Allison Fischer to a mental institution and ordering the involuntary administration of neuroleptic medication by that institution. ${ }^{36}$

At the time of the case, Fischer was a homeless twenty-two year old with no income. She was asking strangers if she could live with them, was expressing grandiose ideas such as winning the World Cup, and was not sleeping regularly. A psychologist testified that she exhibited grossly disturbed behavior and faulty perception. Although Fischer insisted that she was not mentally ill, it is not surprising that the Court of Appeals affirmed the district court holding that she was a danger to self and others and could be committed and treated.

\footnotetext{
34 See eg E.F. Emens, ‘Aggravating Youth: Roper v. Simmons and Age Discrimination’ (2005) 2005 Supreme Court Review 51.

35 Roper v. Simmons, 543 U.S. 551, 569 (2005).

36 In the Matter of the Civil Commitment of Allison Fischer, State of Minnesota Court of Appeals, A071531 (2008).
} 
What gives the case particular interest is that much of Fischer's behaviors and perceptions involved religion. Her grandiose ideas included planning to convert China, Russia, and Africa to Catholicism, she refused to have blood drawn and to remove her clothes on religious grounds, and she was described by her mother as being religiously preoccupied. Moreover, the court did not rely solely on the psychologist presented by the government. The district court appointed a "certified neuropsychiatrist" who found among other things that Fischer "is in a manic phase of bipolar disorder" and that "[s]he does not have the ability to manipulate information rationally." ${ }^{37}$ In the end both the district and appellate courts brushed aside Fischer's explicit freedom of religion claims.

It is not clear from the record what tests this "certified neuropsychiatrist" used, and it is far from clear that the case would have come out differently if the neuropsychiatrist had not testified. But this is a typical example of using science to bolster a case that turns on other factors as well, and it is clear that neuroscience is available to play that role.

Another straw in the wind is the recent decision in Boone v. Missouri, in which an inmate resisted participating in a therapy program on the ground that "the Word of God only has the answers" to his problems and that "only the Lord Jesus Christ and His Holy Spirit can make any necessary changes in my life." ${ }^{38}$ Failure to participate in the program lengthened the amount of time Boone had to spend incarcerated. The court's rejection of Boone's position turned on many factors, but it is worth noting that the Court quoted without disapproval the finding of a therapist that Boone's religious convictions were evidence of "internalized distortions" in his mind. ${ }^{39}$

Fischer and Boone are not leading precedents, and they certainly do not mean that the medical profession is going to begin to view religion generally as an illness or that courts would have any patience with such an approach. ${ }^{40}$ But they do suggest that in close cases, emerging findings relating neuroscience to religion may find a role in some judicial contexts.

37 ibid 3-4.

${ }^{38}$ Boone v. Missouri, 147 S.W. 801, 804 (Court of Appeals of Missouri, Eastern District, 2004).

39 ibid 805.

${ }^{40}$ With the narrow, controversial exception of the "deific decree" doctrine, courts and psychiatrists have long agreed that religious belief should not be viewed as an illness. See eg C. Hawthorne, "'Deific Decree”: The Short, Happy Life of a Pseudo-Doctrine' (2000) 33 Loyola of Los Angeles Law Review 1755; G.H. Morris and A. Haroun, ‘’God Told Me to Kill”: Religion or Delusion?’ (2001) 38 San Diego Law Review 973. 
Given the way the law necessarily works, there is one final paradox that is worth noting here. Consider the hypothetical case I gave concerning a father who suddenly hears the voice of God and therefore does not want to give his daughter traditional medical treatment. Among the factors that a court would consider in the real world is the fact that the father in my hypothetical was not a member of an organized religious group. If he were, by contrast, a life-long Christian Scientist who had come to his views, not because of sudden voices from above, but because of longstanding study of standard Christian Science texts, a court would be more reluctant to view his decision as evidence of mental illness and thus would be more likely to rule in his favor. And this is independent of whatever a brain scan of the father would show. The court would be quite understandably reacting to the fact that the religious exemption to child abuse statutes under consideration were largely supported by and largely aimed at protecting Christian Science and similar established groups such as Jehovah's Witnesses. The fact is that no court is going to medicalize and undermine the religious beliefs of millions of people.

The paradox becomes clear if we look at this from William James' point of view. His defense of the authenticity of religious experience was aimed precisely at the ecstatic and extreme experiences of religious visionaries. He was quite uninterested in the "second-hand" religious life of ordinary parishioners. The law views the matter just the other way around, giving weight to the preferences of well established churches while tending to devalue the spiritual claims of unorthodox individuals. Odd perhaps, but an inevitable byproduct of a system in which science is just one input in a broad effort to resolve cases in a socially acceptable manner. 